\title{
Congenital Myasthenic Syndrome 5
}

National Cancer Institute

\section{Source}

National Cancer Institute. Congenital Myasthenic Syndrome 5. NCI Thesaurus. Code C129304.

Congenital myasthenic syndrome caused by mutation(s) in the COLQ gene, encoding acetylcholinesterase collagenic tail peptide. It is inherited in an autosomal recessive manner. 